\title{
Efek Paparan Subletal Limbah Cair Industri Penyamakan Kulit terhadap Rasio Konversi Pakan dan Laju Pertumbuhan Ikan Nila (Oreochromis niloticus)
}

\section{The Effects of Sublethal Exposure on Tannery Wastewater to the Feed Conversion Ratio and Growth Rate of Tilapia (Oreochromis niloticus)}

\author{
TAUFIQ IHSAN ${ }^{\star}$, TIVANY EDWIN, DAN VIRA ELZA
}

Jurusan Teknik Lingkungan, Fakultas Teknik Universitas Andalas, Kampus Unand Limau Manis, Padang, Sumatra Barat 25163 Email: taufiqihsan@eng.unand.ac.id

\begin{abstract}
Wastewater from the tanning industry of UPTD XX has entered the waters of Batang Anai River, West Sumatra. This wastewater quality exceeds the established quality standards and can be harmful to tilapia as a river biota. This study aimed to analyze the effect of sublethal tannery wastewater on food conversion ratio (FCR) and the specific growth rate (SGR) of tilapia. This study was conducted in three conditions: zero wastewater exposure (control), 1.85\%, and 3.69\% wastewater exposure. Each situation was set in triplo and observed for 28 days. We analyzed the correlation between duration exposure to the FCR and SGR by using regression and correlation analysis. Results showed an increase in the FCR value during observation in both wastewater exposure variations of $1.85 \%$ and $3.69 \%$, with $F C R$ values consecutively 1.19 and 1.75. At the same time, the control experiment showed a decreasing value of FCR. On the contrary, SGR values were decreased during observation in both wastewater exposure variations of $1.85 \%$ and $3.69 \%$, consecutively $3.09 \%$ and $3.72 \%$. While increasing SGR value was observed in the control experiment. A reliable correlation was obtained between the FCR and SGR ratio of tilapia to the exposure duration $(r=0.99)$. Furthermore, multivariate analysis showed a significant difference between the FCR and SGR to the variation and period of direction. It can be concluded that the longer the exposure time and the higher the concentration of exposure, decreasing the food uptake of tilapia and reducing the specific growth rate.
\end{abstract}

Keywords: tilapia, ratio growth rate, tannery wastewater, feed conversion, West Sumatra

\begin{abstract}
ABSTRAK
Limbah cair dari industri penyamakan UPTD XX, Sumatera Barat telah memasuki perairan Sungai Batang Anai, Sumatra Barat. Kualitas air limbah ini melebihi standar kualitas yang ditetapkan dan dapat berbahaya bagi nila sebagai salah satu biota sungai. Penelitian ini bertujuan untuk menganalisis pengaruh air limbah penyamakan kulit terhadap Rasio Konversi Pakan (Food Conversion Ratio/FCR) dan Laju Pertumbuhan Spesifik (Specific Growth Rate/SGR) pada ikan nila. Penelitian ini dilakukan dalam tiga variasi, yakni tanpa paparan air limbah (uji kontrol), paparan air limbah 1,85\% dan 3,69\%. Setiap variasi dilakukan secara triplo dan diamati selama 28 hari. Korelasi antara lama paparan dengan rasio FCR serta SGR, dianalisis dengan menggunakan regresi dan analisis korelasi. Selanjutnya analisis multivariat menggunakan ANOVA twoway untuk melihat perbedaan signifikan FCR dan SGR terhadap variasi dan durasi paparan. Hasil penelitian menunjukkan peningkatan nilai FCR di kedua variasi paparan air limbah 1,85\% dan 3,69\% dengan nilai FCR berturut-turut 1,19 dan 1,75. FCR dalam uji kontrol menunjukkan penurunan nilai FCR. Sebaliknya, nilai SGR cenderung menurun selama pengamatan pada kedua variasi paparan air limbah $1,85 \%$ dan 3,69\%, dengan nilai SGR berturut-turut 3,09\% dan 3,72\%, sementara peningkatan nilai SGR terjadi pada uji kontrol. korelasi yang sangat kuat diperoleh dari nilai FCR dan SGR terhadap durasi paparan $(r=0,99)$. Selanjutnya, uji signifikansi ANOVA menunjukkan perbedaan yang signifikan antara rasio FCR dan SGR dengan variasi dan durasi paparan air limbah. Dapat disimpulkan bahwa semakin lama waktu paparan dan semakin tinggi konsentrasi paparan air limbah, mengurangi serapan pakan ikan nila dan mengurangi tingkat pertumbuhan.
\end{abstract}

Kata kunci: ikan nila, laju pertumbuhan, limbah cair penyamakan kulit, rasio konversi pakan, Sumatra Barat 


\section{PENDAHULUAN}

Industri penyamakan kulit merupakan salah satu industri yang limbahnya berpotensi mencemari lingkungan baik melalui air, tanah maupun udara ${ }^{(1)}$, tidak terkecuali pada industri penyamakan kulit Unit Pelaksana Teknis Dinas (UPTD) XX di Provinsi Sumatra Barat. Proses penyamakan kulit pada UPTD menghasilkan volume limbah cair berkisar $6-8 \mathrm{~m}^{3} /$ ton, yang jika dikalkulasikan menjadi antara $18-40 \mathrm{~m}^{3}$ selama satu minggu atau setara 3,2-8,4 $\mathrm{m}^{3}$ per hari(2).

Berdasarkan hasil uji kualitas limbah cair penyamakan kulit UPTD XX pada outlet Instalasi Pengolahan Air Limbah (IPAL) diperoleh parameter TSS $64 \mathrm{mg} / \mathrm{L}$, COD 113,2 mg/L, BOD $53,27 \mathrm{mg} / \mathrm{L}$, kromium 1,0 mg/L, minyak dan lemak $11,44 \mathrm{mg} / \mathrm{L}$, nitrogen $12,45 \mathrm{mg} / \mathrm{L}$, amonia 1,94 $\mathrm{mg} / \mathrm{L}$, sulfida $1,23 \mathrm{mg} / \mathrm{L}$, dan $\mathrm{pH} 9,4$. Data hasil uji karakteristik limbah cair tersebut telah melebihi baku mutu untuk semua parameter menurut Peraturan Menteri Lingkungan Hidup Nomor 5 Tahun 2014(3). Outlet limbah cair industri penyamakan kulit ini menuju ke Sungai Batang Anai. Keberadaan limbah cair tersebut berpotensi memberikan dampak subletal terhadap ikan sebagai salah satu biota perairan yang ada di sungai. Dampak subletal merupakan dampak biologis, fisiologis atau perilaku pada organisme akibat paparan zat yang berbahaya. Dampak subletal bisa mempengaruhi kemampuan ikan dalam mencerna makanan ${ }^{(4)}$, sehingga dapat menghambat laju pertumbuhan spesifik (Specific Growth Rate/ SGR) ikan, yang disebabkan oleh pertambahan berat ikan yang tidak semestinya. Hambatan pertumbuhan tersebut berhubungan dengan rasio konversi pakan (Food Conversion Ratiol FCR) yang merupakan indeks dari pemanfaatan total pakan untuk pertumbuhan ikan. Menurut $\mathrm{DKPD}^{(5)}$, nilai FCR yang cukup baik berkisar antara $0,8-1,6$ yang berarti $0,8-1,6 \mathrm{~kg}$ pakan dibutuhkan untuk mendapatkan satu kilogram ikan nilai(6).

Ikan nila (Oreochromis niloticus) termasuk jenis ikan yang ada di perairan Sungai Batang Anai dan merupakan makanan lokal dan banyak dikonsumsi oleh masyarakat setempat. Kapasitas produksi ikan nila dapat meningkat dengan menyediakan lingkungan yang sesuai untuk ikan. Oleh sebab itu, diperlukan analisis toksisitas subletal terhadap ikan nila akibat paparan limbah cair industri penyamakan kulit. Selain itu, ikan nila juga sering digunakan sebagai hewan uji toksisitas karena reaktif terhadap perubahan fisik air maupun terhadap adanya senyawa pencemar yang terlarut dalam batas toleransi tertentu ${ }^{(7)}$.

Penelitian subletal dengan mengaitkan rasio konversi pakan dan laju pertumbuhan ikan telah banyak dilakukan ${ }^{(8,9,10)}$. Ini salah satu indikator yang umum digunakan di semua jenis perikanan serta di bidang penelitian toksisitas perairan ${ }^{(11)}$. Tujuan penelitian ini adalah (1) menganalisis nilai rasio konversi pakan dan laju pertumbuhan pada ikan nila yang terpapar limbah cair industri penyamakan kulit UPTD XX; (2) menganalisis pengaruh lama paparan serta variasi konsentrasi limbah cair industri penyamakan kulit UPTD XX terhadap rasio konversi pakan dan laju pertumbuhan ikan nila secara statistik.

\section{BAHAN DAN METODE}

\subsection{Bahan}

Peralatan yang digunakan untuk penelitian ini adalah akuarium berbahan akrilik, berbentuk persegi panjang dengan ukuran $(35 \times 30 \times 30) \mathrm{cm}^{3}$ sebanyak sembilan buah. Volume air yang digunakan dalam satu akuarium yaitu 23 liter. Dari total akuarium yang digunakan, tiga akuarium sebagai uji kontrol, tiga akuarium untuk konsentrasi 1/14 LC50-96h (1,85\%) dan tiga akuarium untuk konsentrasi 1/7 LC50-96h $(3,69 \%)$ limbah cair penyamakan kulit. Nilai LC5096h mengacu pada penelitian Edwin dkk ${ }^{(12)}$ yang melakukan pengujian toksisitas akut limbah cair industri penyamakan kulit terhadap ikan nila. Masing-masing akuarium dilengkapi dengan aerator. Pengukuran $\mathrm{DO}, \mathrm{pH}$ dan suhu dalam akuarium dilakukan dengan DO meter, $\mathrm{pH}$ meter, dan termometer.

\subsection{Pengambilan Sampel Limbah Cair Penyamakan Kulit}

Larutan uji yang digunakan untuk penelitian ini yaitu limbah cair penyamakan kulit UPTD XX. Pengambilan limbah cair dilakukan di outlet Instalasi Pengolahan Air Limbah UPTD Pengolahan Kulit Padang Panjang. Pengambilan sampel dilakukan pada bulan Oktober 2019.

\subsection{Pemilihan Hewan Uji}

Penelitian menggunakan hewan uji ikan nila dengan ukuran 4-5 cm, berat ikan 2-3 gram, umur \pm 1 bulan, jumlah ikan yang digunakan 45 ekor di mana satu akuarium terdiri dari lima ekor ikan ${ }^{(13)}$. Akuarium ini diisi air yang volumenya disesuaikan dengan jumlah ikan, yaitu satu liter air untuk 0,8 gram berat ikan ${ }^{(14)}$. Pemindahan hewan uji menuju laboratorium menggunakan kantong plastik dengan ukuran transparan yang diberi oksigen ${ }^{(15)}$.

\subsection{Aklimatisasi Hewan Uji}

Aklimatisasi ini dilakukan selama tujuh hari ${ }^{(14)}$. Ikan nila diberi makanan berupa pelet ikan setiap tiga kali sehari serta diberikan pakan sebesar 3\% dari bobot ikan per hari ${ }^{(16)}$. 


\subsection{Uji Subletal terhadap Rasio Konversi Pakan}

Penelitian dilakukan dengan pengulangan tiga kali (triplo) dengan penambahan konsentrasi limbah cair pada masing-masing akuarium. Besarnya rasio konversi pakan/Food Conversion Ratio (FCR) dihitung dengan menggunakan rumus berikut ${ }^{(17):}$

$$
\mathrm{FCR}=\frac{\text { Jumlah pakan yang diberikan }(\mathrm{g})}{\left(\mathrm{W}_{\mathrm{t}}+\mathrm{D}\right)-\mathrm{W}_{\mathrm{o}}(\mathrm{g})}
$$

\section{Keterangan:}

$\mathrm{FCR}=$ Rasio Konversi Pakan

$\mathrm{W}_{0}=$ Berat hewan uji penelitian $(\mathrm{g})$

$\mathrm{W}_{\mathrm{t}} \quad=$ Berat hewan uji akhir penelitian $(\mathrm{g})$

D = Jumlah ikan yang mati

Langkah kerja pengambilan data parameter rasio konversi pakan:

a. Timbang berat ikan pada masing-masing akuarium, di mana satu akuarium terdiri dari lima ekor ikan, selanjutnya ditimbang dengan neraca analitik setiap hari $(\mathrm{W})$. $\mathrm{W}_{\mathrm{o}}$ adalah berat hewan uji sebelum hari ke-t dan $W_{t}$ adalah berat hewan uji pada hari ke t;

b. Timbang berat pakan yang diberikan pada hari ke-t untuk masing-masing akuarium yaitu 3\% dari berat hewan uji pada hari ke-t $\left(\mathrm{W}_{\mathrm{t}}\right)$. Ikan nila diberi makan sebanyak tiga kali sehari.

\subsection{Uji Subletal terhadap Laju Pertumbuhan Ikan}

Laju pertumbuhan spesifik/Specific Growth Rate (SGR) pada ikan nila diamati dengan melakukan pengukuran terhadap berat ikan nila. Selama masa percobaan, data pengukuran untuk masing-masing parameter yang digunakan pada analisis regresi dan korelasi adalah data pada hari ke-1, hari ke-7, hari ke-14, hari ke-21 dan hari ke28. Besarnya laju pertumbuhan ikan nila dapat dihitung dengan menggunakan rumus Steffens, $1989^{(18)}$.

$\mathrm{SGR}=\frac{\left(\ln \mathrm{W}_{\mathrm{t}}-\ln \mathrm{W}_{\mathrm{o}}\right)(\mathrm{g}) \times 100 \%}{(\mathrm{t}) \text { hari }}$

Keterangan:

SGR = Laju pertumbuhan

$\mathrm{W}_{\mathrm{t}} \quad=$ Berat hewan uji akhir penelitian $(\mathrm{g})$

$$
\begin{array}{ll}
\mathrm{W}_{\circ} & =\text { Berat hewan uji penelitian }(\mathrm{g}) \\
\mathrm{t} & =\text { Waktu penelitian (hari) }
\end{array}
$$

\subsection{Analisis korelasi, regresi, dan ANOVA}

Data yang diperoleh, dianalisis secara statistik. Analisis regresi dan korelasi dilakukan untuk melihat korelasi durasi paparan limbah cair penyamakan kulit terhadap rasio konversi pakan (FCR) dan laju pertumbuhan spesifik (SGR) ikan nila. Kemudian analisis multivariat menggunakan two-way ANOVA dilakukan untuk melihat perbedaan nyata antara variasi konsentrasi pada limbah cair industri penyamakan kulit

\section{HASIL DAN PEMBAHASAN}

\subsection{Aklimatisasi Hewan Uji}

Aklimatisasi hewan uji dilakukan selama tujuh hari untuk mengondisikan hewan uji agar bisa beradaptasi dengan keadaan lingkungan laboratorium ${ }^{(14)}$. Berdasarkan hasil pengamatan selama aklimatisasi, kematian hewan uji $<3 \%{ }^{(16)}$. Kondisi lingkungan air selama aklimatisasi didapatkan bahwa nilai kadar oksigen terlarut $6,70-8,00 \mathrm{mgO}_{2} / \mathrm{l}$, nilai $\mathrm{pH}$ didapatkan $7,30-8,10$ dan nilai suhu didapatkan $25,6-26,90^{\circ} \mathrm{C}$. Menurut USEPA ${ }^{(18)}$ rentang DO yang diperbolehkan berkisar $>4 \mathrm{mgO}_{2} / \mathrm{l}, \mathrm{pH}$ yang diperbolehkan berkisar 6-9 dan suhu yang diperbolehkan yaitu $25-30^{\circ} \mathrm{C}$. Dapat dikatakan bahwa pada saat aklimatisasi nilai $\mathrm{DO}, \mathrm{pH}$, dan suhu yang didapatkan masih berada pada rentang yang diperbolehkan.

\subsection{Kondisi Lingkungan}

Selama masa penelitian (28 hari), beberapa faktor terus dipantau agar memenuhi syarat pemeliharaan ikan nila sehingga sesuai dengan standar yang telah ditetapkan USEPA untuk pengujian toksisitas pada ikan. Faktor tersebut adalah DO, pH dan suhu, yang hasil dari pengamatan dapat dilihat pada Tabel 1.

Berdasarkan Tabel 1 tersebut, kondisi lingkungan ( $\mathrm{DO}, \mathrm{pH}$ dan suhu) berada pada rentang yang diperbolehkan. Dengan kondisi parameter seperti ini, berarti penelitian terkait pengujian toksisitas sudah sesuai dengan acuan USEPA $^{(19)}$.

Tabel 1. Parameter fisikokimia air selama pengamatan 28 hari

\begin{tabular}{lcccc}
\hline \multicolumn{1}{c}{ Faktor } & Kontrol & $\mathbf{1 , 8 5 \%}$ & $\mathbf{3 , 6 8} \%$ & Standar USEPA \\
\hline $\mathrm{DO}\left(\mathrm{mg} \mathrm{O}_{2} / \mathrm{L}\right)$ & $7,01 \pm 0,15$ & $6,91 \pm 0,10$ & $6,78 \pm 0,05$ & $>4$ \\
\hline $\mathrm{pH}$ & $7,07 \pm 0,10$ & $7,84 \pm 0,10$ & $7,93 \pm 0,15$ & $6-9$ \\
\hline Suhu $\left({ }^{0} \mathrm{C}\right)$ & $27,04 \pm 0,10$ & $26,95 \pm 0,05$ & $26,97 \pm 0,05$ & $25-30$ \\
\hline
\end{tabular}




\subsection{Rasio Konversi Pakan (FCR)}

Nilai dari rasio konversi pakan pada ikan nila didapatkan berdasarkan Persamaan 1. Grafik hubungan antara rasio konversi pakan ikan nila terhadap waktu pengamatan dapat dilihat pada Gambar 1. Berdasarkan Gambar 1, diketahui bahwa terjadi kenaikan nilai FCR pada percobaan dengan pemaparan limbah cair penyamakan kulit UPTD Padang Panjang mulai dari pengamatan hari ke-1 hingga hari ke-28. Sedangkan pada percobaan kontrol, FCR mengalami penurunan. Pada pengamatan hari ke-21, nilai FCR pada percobaan dengan $3,69 \%$ paparan limbah sebesar 1,89 $\pm 0,29$ yang berarti di luar rentang FCR ikan yang normal, yakni sebesar $0,8-1,6^{(5)}$. Sedangkan pada percobaan dengan paparan limbah $1,85 \%$, nilai FCR berada di luar rentang pada pengamatan hari ke-28, yakni sebesar $1,79 \pm 0,29$. Rasio konversi pakan yang cenderung meningkat menunjukkan terjadinya penurunan pakan yang dikonsumsi ikan. Kandungan limbah dapat mempengaruhi sistem respirasi pada ikan yang dapat menyebabkan ikan mengalami hipoksia, sehingga nafsu makan ikan menjadi berkurang. Hal tersebut dapat mempengaruhi nilai FCR yang didapatkan ${ }^{(20-26)}$.

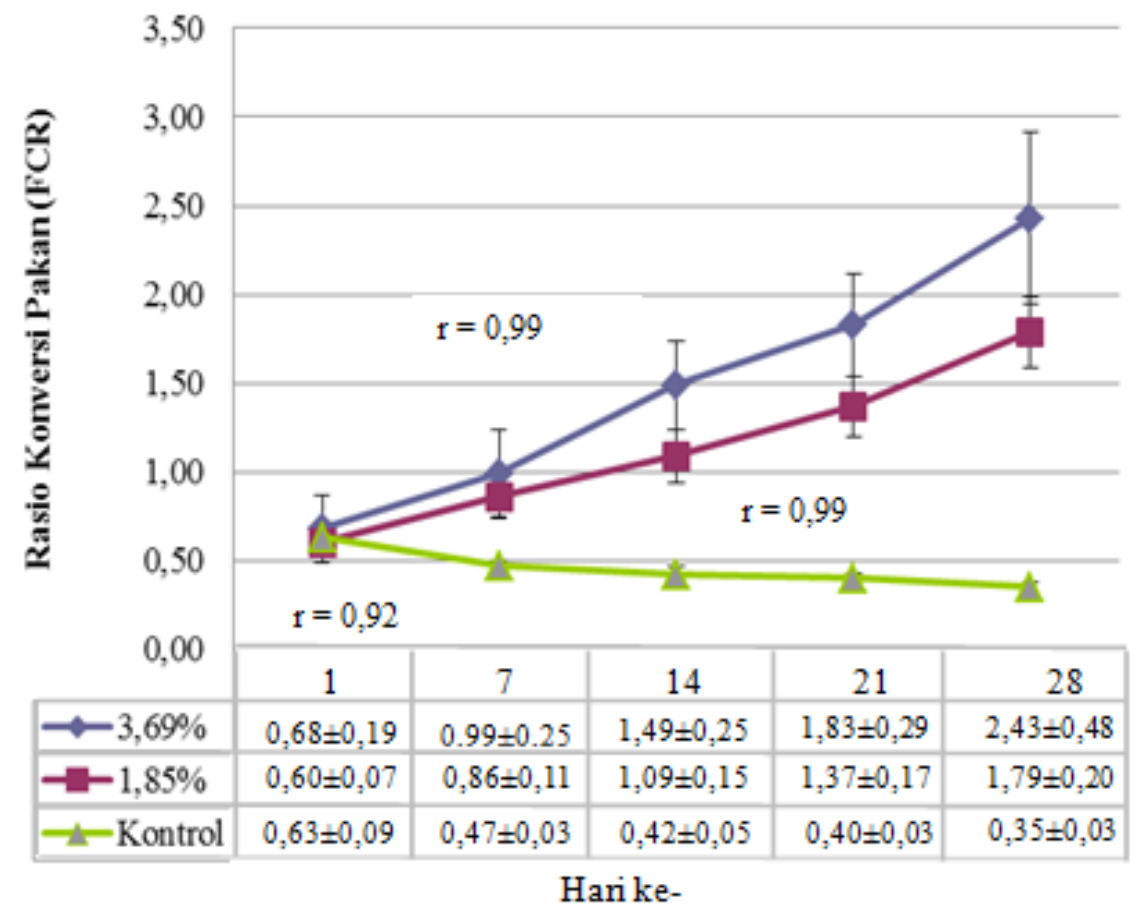

Gambar 1. Rasio konversi pakan akibat paparan limbah terhadap waktu pengamatan

Berdasarkan lama paparan diperoleh nilai korelasi 0,99 pada percobaan dengan paparan limbah cair penyamakan kulit 1,85\% dan 3,69\%. Berdasarkan nilai korelasi tersebut, disimpulkan bahwa waktu pengamatan dan rasio konversi pakan ikan nila memiliki hubungannya sangat kuat. Berdasarkan hasil uji two-way ANOVA diperoleh nilai probabilitas ( $p$ ) sebesar 0,000 $(p<0,05)$ pada rasio konversi pakan terhadap lama pemaparan dan terhadap variasi paparan limbah cair dengan tingkat kepercayaan 95\%. Hal ini berarti bahwa nilai FCR berdasarkan lama waktu paparan dan variasi paparan limbah berbeda signifikan.

\subsection{Laju Pertumbuhan Spesifik (SGR)}

Pada keadaan normal, apabila aktivitas metabolisme berjalan dengan baik, maka akan terjadi peningkatan pada laju pertumbuhan ikan ${ }^{(27)}$. Nilai SGR pada ikan nila didapatkan berdasarkan Persamaan 2. Grafik hubungan antara SGR ikan nila terhadap waktu pengamatan dapat dilihat pada Gambar 2. Secara umum laju pertumbuhan ikan pada percobaan kontrol mengalami kenaikan sepanjang waktu pengamatan. Hal ini berbeda dengan percobaan dengan paparan limbah yang menunjukkan penurunan. Pada Percobaan kontrol, terjadi kenaikan SGR sebesar 3,67\%. Sebaliknya pada percobaan dengan paparan $1,85 \%$ limbah cair terjadi penurunan SGR sebesar 3,09\% dan pada konsentrasi $3,69 \%$ sebesar $3,72 \%$. Laju pertumbuhan normal ikan idealnya mengalami kenaikan berkisar di atas $2,52 \%(28)$, meskipun ini nanti akan dipengaruhi juga oleh genetika ikan serta kualitas bahan pakan yang diberikan ${ }^{(29)}$. Semakin lama terpapar dan semakin besar 
konsentrasi paparan zat toksik, maka akan semakin terjadi penurunan laju pertumbuhan ikan.

Terjadinya perbedaan dan penurunan laju pertumbuhan ikan nila disebabkan karena paparan limbah cair yang diberikan. Pengaruh paparan dari limbah cair yang menyebabkan ikan tersebut kurang mengonsumsi pakan ${ }^{(20,22,23)}$. Penurunan laju pertumbuhan ikan terjadi karena organ tubuh ikan mengalami gangguan sehingga mengurangi nafsu makan. Pemanfaatan energi yang berasal dari makanan lebih banyak digunakan untuk mempertahankan diri dari tekanan lingkungan serta mengganti bagian sel yang rusak akibat kontaminasi dengan bahan toksik. Hal ini mengakibatkan terganggu proses metabolisme di dalam tubuh ikan yang dapat dilihat dengan adanya perubahan perilaku pada ikan (30-32).

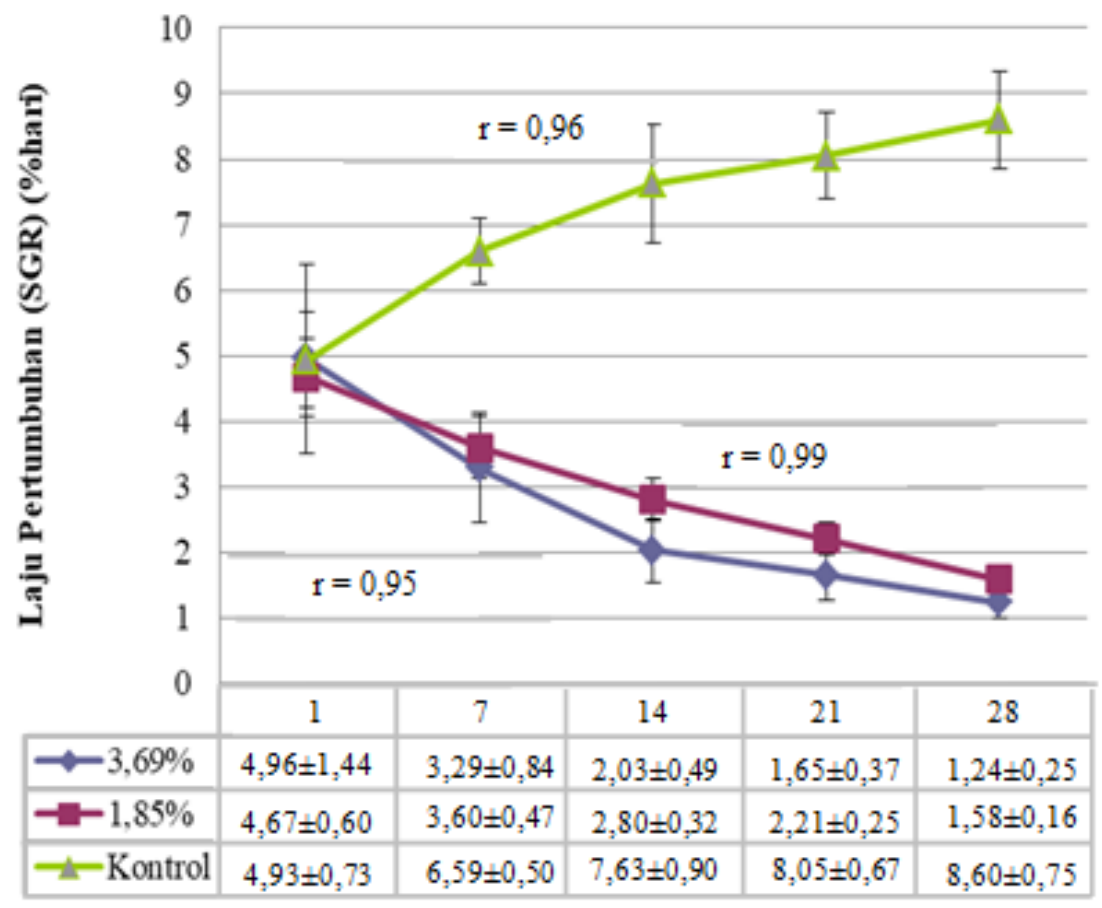

Hari ke-

Gambar 2. Laju pertumbuhan akibat paparan limbah terhadap waktu pengamatan

Pada percobaan dengan paparan 1,85\% limbah cair penyamakan kulit didapatkan nilai korelasinya sebesar 0,99. Sementara itu pada percobaan dengan paparan 3,69\% limbah cair penyamakan kulit korelasi yang didapatkan sebesar 0,95. Berdasarkan nilai tersebut, lama paparan limbah cair menunjukkan korelasi yang sangat kuat terhadap laju pertumbuhan spesifik ikan. Berdasarkan uji two-way ANOVA didapatkan nilai probabilitas $(p)$ sebesar $0,000(p<0,05)$ pada laju pertumbuhan pada ikan nila terhadap lama pemaparan dan variasi paparan limbah cair dengan tingkat kepercayaan 95\%. Hal ini berarti bahwa laju pertumbuhan berbeda signifikan berdasarkan lama dan variasi paparan limbah cair penyamakan kulit.

\subsection{Hubungan Antara FCR dengan SGR terhadap Paparan Limbah Cair Penyamakan Kulit UPTD Padang Panjang}

Secara teori, rasio konversi pakan berbanding lurus dengan laju pertumbuhan spesifik ikan nila. Sesuai dengan hasil yang didapatkan pada penelitian ini di mana pada Gambar 3 dapat disimpulkan bahwa semakin tinggi konsentrasi paparan limbah cair penyamakan kulit, maka rasio konversi pakan ikan nila semakin meningkat dan laju pertumbuhannya semakin menurun. Namun pada percobaan kontrol (kondisi normal) yang tidak terpapar limbah cair penyamakan kulit, seiring berjalannya waktu maka rasio konversi pakan menurun dan laju pertumbuhan meningkat. 


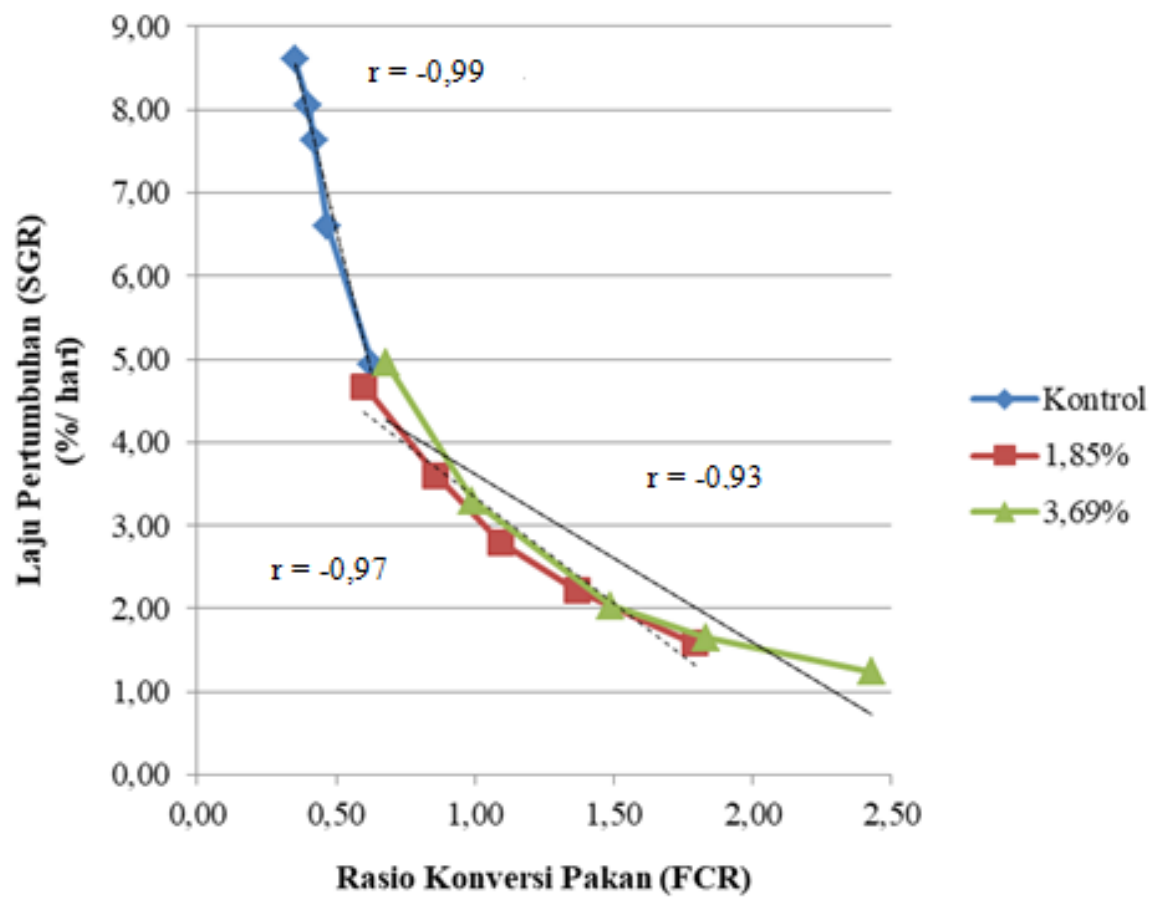

Gambar 3. Hubungan laju pertumbuhan dengan rasio konversi pakan pada ikan nila

Berdasarkan hasil analisis korelasi didapatkan rentang korelasi pada ketiga variasi percobaan -0,93-0,99 yang berarti nilai FCR berbanding terbalik dengan korelasi yang sangat kuat dengan nilai SGR. Penyebab terjadinya peningkatan rasio konversi pakan dan penurunan laju pertumbuhan ikan nila yang terpapar limbah cair penyamakan kulit yang disebabkan karena pengaruh toksik dari limbah cair industri. Pengaruh hubungan rasio konversi pakan dengan laju pertumbuhan akibat limbah cair dapat berimplikasi terhadap terganggunya kesehatan lingkungan perairan seperti munculnya penyakit dan kematian pada biota di perairan.

\section{KESIMPULAN}

Berdasarkan hasil penelitian didapatkan bahwa paparan limbah dapat mempengaruhi rasio konversi pakan (FCR) dan laju pertumbuhan spesifik (SGR) pada ikan nila di mana terdapat kenaikan FCR pada percobaan dengan paparan limbah $1,85 \%$ dan $3,69 \%$, sedangkan pada percobaan kontrol FCR mengalami penurunan. Nilai FCR berbeda signifikan terhadap lama paparan dan variasi paparan limbah. Laju pertumbuhan spesifik (SGR) ikan nila mengalami penurunan pada percobaan dengan paparan limbah 1,85\% dan 3,69\%, sedangkan pada percobaan kontrol SGR mengalami peningkatan. Nilai FCR berbeda signifikan terhadap lama paparan dan variasi paparan limbah. Semakin lama waktu pemaparan dan semakin tinggi konsentrasi paparan limbah cair maka rasio konversi pakan ikan nila semakin meningkat dan laju penurunan semakin menurun. Hal ini dapat terlihat pada nilai korelasi yang didapatkan yaitu 0,99 yang berarti hubungannya sangat kuat antara rasio konversi pakan dan laju pertumbuhan ikan nila terhadap lama paparan.

Berdasarkan hasil penelitian ini, maka perlu dilakukan pengawasan terkait outlet limbah industri ke sungai sejak dari pengontrolan terhadap keberadaan dan keefektifan IPAL dalam mengolah limbah cair sebelum masuk ke badan perairan harus memenuhi baku mutu yang ditetapkan. Selanjutnya dengan analisis spasial pada sungai tersebut, akan dapat memberikan pemetaan dan gambaran lokasi suatu jenis usaha/ kegiatan yang tepat, termasuk kegiatan pembudidayaan ikan

\section{PERSANTUNAN}

Penulis menyampaikan puji syukur pada Allah Tuhan YME sehingga penelitian telah dapat diselesaikan. Terima kasih kepada Jurusan Teknik Lingkungan Universitas Andalas serta UPTD Padang Panjang yang telah memberikan dukungan dalam proses penelitian ini.

\section{DAFTAR PUSTAKA}

1. Sunaryo, I., Sutyasmi, S. (2011). Manfaat Limbah Padat Industri Penyamakan Kulit dan Pengelolaannya. Prosiding Workshop Penelitian dan Pengembangan Kulit, Karet dan Plastik. Indonesia, BBKKP. Yogyakarta. 
2. UPTD Padang Panjang. (2019). Profil UPTD Pengolahan Kulit Kota Padang Panjang. UPTD Pengolahan Kulit: Padang Panjang.

3. Peraturan Menteri Lingkungan Hidup Republik Indonesia Nomor 5 Tahun 2014 Tentang Baku Mutu Air Limbah.

4. Mondon, J. A., Duda, S., Nowak, B. F. (2001). Histological, Growth and 7 Ethoxyresorufin odeethylase (erod) Activity Responses of Greenback Flounder Rhombosolea tapirina to Contaminated Marine Sediment and Diet. Aguat. Toxicolocy. 54(2): 231-246. doi.org/10.1016/S0166-445X(01)00146-1.

5. DKPD (Dinas Kelautan dan Perikanan Daerah). (2010). Petunjuk Teknis Pembenihan dan Pembesaran Ikan Nila. Dinas Kelautan dan Perikanan. Sulawesi Tengah.

6. Ihsan, T., Edwin, T., Anggraeni W. (2018). Behavioral responses of Nile tilapia (Oreochromis niloticus) by sublethal exposure to chlorpyrifos: a case study in Twin Lakes of West Sumatra. Environmental Health Engineering and Management Journal. 5(4): 205-210. doi.org/10.15171/EHEM.2018.28.

7. Chahaya, S. I. (2003). Ikan sebagai Alat Monitor Pencemaran. Tugas Akhir Bagian Kesehatan Lingkungan Fakultas Kesehatan Masyarakat. Universitas Sumatera Utara. Sumatera Utara.

8. Kusriani, P., Widjanarko., Rohmawati, N. (2012). Uji Pengaruh Sublethal Pestisida Diazinon 60 EC terhadap Rasio Konversi Pakan (FCR) dan Pertumbuhan Ikan Mas (Cyprinus carpio L.). Journal of Fisheries and Marine Research. 1(1):36-42.

9. Dube P. N., Hosetti, B. B. (2010). Behaviour Surveillance and Oxygen Consumption in The Freshwater Fish Labeo rohita (Hamilton) Exposed to Sodium Cyanide. Biotechnology in Animal Husbandry. 26 (1-2):91-103.

10. Handeland, S. O., Imsland, A. K., Stefansson, S. O. (2008). The effect of temperature and fish size on growth, feed intake, food conversion efficiency and stomach evacuation rate of Atlantic salmon post-smolts. Aquaculture. $\quad 283(1-4): \quad 36-42$. doi.org/10.1016/j.aquaculture.2008.06.042.

11. Alexander, P., Brown, C., Dias, C., Moran, D., Rounsevell, M. D. A. (2019). Chapter 1 Sustainable Proteins Production, Editor(s): Charis M. Galanakis,Proteins: Sustainable Source, Processing and Applications, Academic Press,Pages 1-39,ISBN 9780128166956.
12. Edwin, T., Ihsan, T., Ananda, M.A., Guspariani, G. (2018). Acute And Sub-Lethal Toxicity Test on Oreochromis niloticus Exposed with Tannery Wastewater. Int. J. Adv. Res. 6(5): 2320-5407. doi.org/10.21474/IJAR01/7091.

13. Halappa, R., David, M. (2009). Behavioural responses of the freshwater fish, Cyprinus carpio (Linnaeus) following sublethal exposure to chlorpyrifos. Turkish Journal of Fisheries and Aquatic Sciences. 9: 233-238. doi.org/10.4194/ trjfas.2009.0218.

14. APHA (American Public Health Association), AWWA (American Water Works Association), WEF (Water Environment Federation). (2014). Standard Methods for the Examination of Water and Wastewater, 22nd. Washington DC.

15. Legendre, M., Pouyaud, L., Slembrouck, J., Gustiano, R., Kristanto, A. H., Subagja, J., Komarudin, O., Maskur. (2000). Pangasius djambal: A new candidate species for fish culture in Indonesia. Journal IARD. 22(1): 114.

16. Suyanto, S.R. (2009). Nila. Penebar Swadaya. Jakarta.

17. Imanpoor, M., Ahmad R. A., Kabir, M. (2011). Effect of Sublethal Concentration of Chloramine $T$ on Growth, Survival, Haematocrit and some Blood Biochemical Parameters in Common Carp Fry (Cyprinus carpio). Jurnal of the Bioflux Society. 4(3):281282.

18. Damayanty, M. M., Nurlita A. (2013). Pengaruh Paparan Sub Lethal Insektisida Diazinon 600 EC terhadap Laju Konsumsi Oksigen dan Laju Pertumbuhan Ikan Mujair (Oreochromis mossambicus). Jurnal Sains dan Seni Pomits. 2(2): 2337-3520.

19. United States Environmental Protection Agency (USEPA). Methods for Measuring the Acute Toxicity of Effluents and Receiving Waters to Freshwater and Marine Organisms. 5th ed. Washington, DC: EPA; 2002.

20. Besson, M., Aubin, J., Komen, H., Poelman, M., Quillet, E., Vandeputte, M., van Arendonk, J. A. M., de Boer, I. J. M. (2016). Environmental impacts of genetic improvement of growth rate and feed conversion ratio in fish farming under rearing density and nitrogen output limitations. Journal of Cleaner Production. 116:100-109. doi.org/10.1016/j.jclepro.2015.12.084.

21. Cresson, P., Travers-Trolet, M., Rouquette, M., Timmerman, C., Giraldo, C., Lefebvre, S., 
Ernande, B. (2017). Underestimation of chemical contamination in marine fish muscle tissue can be reduced by considering variable wet:dry weight ratios. Marine Pollution Bulletin. 123: 279-285. doi.org/10.1016/j.marpolbul.2017.08.046.

22. Omasaki, S.K., Janssen, K., Besson, M., Komen, H. (2017). Economic values of growth rate, feed intake, feed conversion ratio, mortality and uniformity for Nile tilapia, Aquaculture. 481: 124-132. doi.org/10.1016/j.aquaculture.2017.04.013.

23. Hoseini, S.M., Yousefi, M., Hoseinifar, S.H., Van-Doan, H. (2019). Effects of dietary arginine supplementation on growth, biochemical, and immunological responses of common carp (Cyprinus carpio L.), stressed by stocking density. Aquaculture. 503:452459.

doi.org/10.1016/j.aquaculture.2019.01.031.

24. Zhou, Y., Luo, W., Yu, X., Liu, Q., Tong, J. (2019). Brain and intestine transcriptome analyses and identification of genes involved in feed conversion efficiency of Yellow River carp (Cyprinus carpio haematopterus) Comparative Biochemistry and Physiology Part D: Genomics and Proteomics. 29: 221227. doi.org/10.1016/j.cbd.2018.12.004.

25. Ihsan, T., Edwin, T., Yanti, R. D. (2019). The Effect of Sublethal Exposure of Chlorpyrifos to Nile Tilapia (Oreochromis niloticus): Case Study of Twin Lakes of West Sumatra, Indonesia, Nature Environment \& Pollution Technology, 18(4):1399-1403.

26. Mallaya, J., Yovita. (2007). The Effect of Dissolved Oxygen on Fish Growth in Aquaculture. Kingolwira National Fish
Farming centre, Fisheries Division Ministry of Natural Resources and Tourism Tanzania.

27. Fujaya, Y. 2004. Fisiologi Ikan. Rineka Cipta. Jakarta.

28. Lugert, V., Thaller, G., Tetens, J., Schulz, C., Krieter, J. (2014). A review on fish growth calculation: multiple functions in fish production and their specific application. Reviews in Aquaculture. 8(1), 30-42. doi.org/10.1111/raq.12071.

29. Arthur, P.F., Pryce, J.E., Herd, R.M. (2014). Lessons Learnt from 25 Years of Feed Efficiency Research in Australia. Proceedings, 10th World Congress of Genetics Applied to Livestock Production.

30. Zeng, L.Q., Fu, C., Fu, S.J. (2018). The effects of temperature and food availability on growth, flexibility in metabolic rates and their relationships in juvenile common carp. Comparative Biochemistry and Physiology Part A: Molecular \& Integrative Physiology. 217:

26-34. doi.org/10.1016/j.cbpa.2017.12.011.

31. Ai, F., Wang, L., Li, J., Xu, Q. (2019). Effects of a-ketoglutarate (AKG) supplementation in low phosphorus diets on the growth, phosphorus metabolism and skeletal development of juvenile mirror carp (Cyprinus carpio). Aquaculture, 507:393-401. doi.org/10.1016/j.aquaculture.2019.03.047.

32. Gjerde, B., Kanta D. Mahapatra, Padala V.G.K., Saha, R.J.N, Jana, R.K., Meher, P.K., Sahoo, M., Khaw, H.L., Gjedrem, T., Rye, M. (2019). Genetic parameters for growth and survival in rohu carp (Labeo rohita). Aquaculture. $\quad 503$ : 381-388. doi.org/10.1016/j.aquaculture.2019.01.029. 